\title{
The Healing Village of Malaysia: from Local Wisdoms to Implementation
}

\section{Badaruddin Mohamed}

Sustainable Tourism Research Cluster (STRC), Universiti Sains Malaysia

Diana Mohamad

School of Housing, Building \& Planning (HBP), Universiti Sains Malaysia

Azizan Marzuki

Sustainable Tourism Research Cluster (STRC), Universiti Sains Malaysia

Nor'Azam Shuib

School of Housing, Building \& Planning (HBP), Universiti Sains Malaysia

Salasiah Che Lah

School of Humanities, Universiti Sains Malaysia, Penang, Malaysia

A.S Hardy Shafii

School of The Arts, Universiti Sains Malaysia, Penang, Malaysia

\begin{abstract}
Rapid urbanization, hectic lifestyle, and increased cost of living, have resulted significant impacts to the mental and physical well-being of Malaysians in general, especially those living the urban areas like the capital city of Kuala Lumpur, and the heritage cities of Penang and Malacca. These have resulted to the much needed demand for recuperation and revitalization. While, more and more types of healing therapies such as Balinese Spa, Thai Massage, Swedish Spa and Turkish Bath, dominating the healing market in Malaysia, the state of art of the Malay traditional spa is at stake. Thus, the call of an intervention on the decline of this type of spa resulted in the developmental framework of a healing village concept. This paper reports on the development of a healing village concept which integrates the uniqueness of the Malays local knowledge and culture in revitalizing a holistic wellness. Kampung Batu Hampar, located in Beseri, Malaysia, has been selected as the site for the Healing Village Project. This Project develops four subprograms, namely Cultural Troupe, Herbs Garden, Kampung (village) Stay and Malay Traditional Therapy---as the agent of recuperative for the Malaysians. In particular, these subprograms involve the following healing dimensions: socio-economic, culture, people and environment. The development of these four subprograms is based on the natural resources observed in Kampung Batu Hampar as well as findings revealed by informal interviews with the villagers.
\end{abstract}

Keywords: Healing Village, Malay Traditional Culture, village tourism, Herbs 